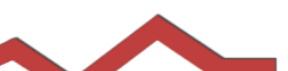

\title{
Artvin Rize Havalimanı'nın Ulaşıma ve Çevreye Etkileri
}

\author{
Merve ERDOĞAN ${ }^{1 *(D)}$, Özge YALÇINER ERCOŞKUN ${ }^{1}$ (D) \\ ORCID 1: 0000-0001-6628-1018 \\ ORCID 2: 0000-0003-2734-0374 \\ ${ }^{1}$ Gazi Üniversitesi, Fen Bilimleri Enstitüsü, Trafik Planlaması ve Uygulaması Ana Bilim Dalı, 06570, Ankara, \\ Türkiye. \\ *e-mail: merve9561@gmail.com
}

\section{Öz}

Ulaşımda, hızlı ve konforlu yolcu taşımacılığı sunan havayolu ulaşımına her geçen gün talep artmaktadır. Bu durum havalimanı yatırımlarını da beraberinde getirmektedir. Havalimanı yatırımları ekonomik ve sosyal olarak katkılar sağlasa da birçok olumsuz çevresel etkileri bulunmaktadır. Havalimanları için yeterli alan bulunmadığında tercih edilen deniz dolgu alanları olumsuz çevresel etkileri artırmaktadır. Başta hava kirliliği ve su kirliliği olmak üzere denizdeki canlı ve bitki türlerinin azalması, iklim değişikliği, toprak kirliliği gibi olumsuz etkilere neden olmaktadır. Önlem alınmadığı takdirde geri dönüşü olmayan hasarlar oluşmaktadır. Bu sebeple yatırımın gerekliliği iyi analiz edilmeli, çevreye verilebilecek zarar en aza indirilmeli, alınacak önlemler planlanmalıdır. Yapılan çalışmada Artvin-Rize Havalimanı'nın inşaat sürecinde ve hizmete açıldıktan sonra oluşabilecek çevresel etkiler konulmuştur. Olumlu ve olumsuz yanları irdelenmiş, öneriler geliştirilmiştir.

Anahtar Kelimeler: Artvin-Rize Havalimanı, dolgu alanı, çevresel etkiler

\section{Impacts of Artvin Rize Airport on Transportation and Environment}

\begin{abstract}
In transportation, the demand for air transportation, that serves fast and comfortable passenger transportation, increases day by day. This situation triggers airport investments. Although airport investments make economic and social contributions, they cause many negative environmental impacts. When there is not sufficient area for airports, offshore infill areas increase the negative environmental impacts. The reduction of living and plant species in the sea, air and water pollution, cause adverse impacts such as climate change and soil pollution. If precautions are not taken, irreversible damage will occur. For this reason, the necessity of the investment should be well analyzed, the damage to the environment should be minimized, and the measures should be planned. In the study, the environmental effects that may occur during the construction process of Artvin-Rize Airport and after launch were examined. The positive and negative aspects were put and recommendations were made.
\end{abstract}

Keywords: Artvin Rize Airport, infill areas, environmental impacts

Atıf/Citation: Erdoğan, M, Yalçıner Ercoşkun, Ö. (2021). Artvin Rize Havalimanı'nın Ulaşıma ve Çevreye Etkileri. Journal of Architectural Sciences and Applications, 6 (1), 250-267. DOI: 10.30785/mbud.871204 


\section{Giriş}

Gelişen teknolojik gelişmeler, ulaşım sistemlerinin de gelişmesini sağlamıştır. Uzun mesafelere kısa sürelerde ulaşmayı sağlayan havayolu taşımacılığı, sunduğu hizmet ve gelişen teknolojiyle birlikte artan konfor, güvenilirlik ve hız sebebiyle cazip bir seçenek olarak görülmektedir. Öyle ki dünya çapında gittikçe artan bir havayolu ağı oluşmuştur. Gün içinde küresel ölçekte binlerce uçak hava trafiğinde yer almakta, yolcu ve kargo taşımacılığı yapmaktadır (Arabacı, 2010, s. 1).

Ülkemizde de havayolu taşımacılığı hızla gelişmektedir. DHMi verilerine göre 2003 yılında 9.147 bin olan iç hattaki yolcu sayısı, 2019 yılına gelindiğinde 112.759 bine ulaşmıştır. 2003 yılında 162 tane olan uçak sayısı 2019 yılında 546 tane olmuş, son 17 yılda \%237 artış sağlanmıştır (Sivil Havacılık Genel Müdürlüğü, 2019). DHMi'den alınan verilere göre ülkemizde seyahatlerde havayolunu tercih eden kişi sayısında artış görülmektedir. Havalimanı olmayan yerlere ise en yakın havalimanına yolculuk edilip karayolu aktarmalı olarak devam edilmektedir. Ülkemizde havayolunun yaygınlaşmasını sağlamak için havalimanlarının sayısı artırılmaktadır. Ülkemizdeki uçuş noktaları 2003 yılında 26 iken 2019 yıına gelindiğinde 56'ya yükselmiştir (Sivil Havacılık Genel Müdürlüğü, 2019). Havalimanlarının artması ulaşımı kolaylaştırmakla kalmayıp bulunduğu bölgeye istihdam da sağlamaktadır.

Öte yandan havalimanlarının birçok olumsuz çevresel etkileri de ortaya konulmaktadır. Bu konularla ilgili çeşitli araştırmalar bulunmaktadır. Örneğin havacılık sektörü $\mathrm{CO}_{2}$ gazı yayan uçaklar nedeniyle sera gazları arasında en hızlı büyüyen unvanına sahiptir. Havayolu ağının küresel ölçekte geldiği noktaya bakılacak olursa ciddi önlemlerin alınması gerekmektedir. $\mathrm{CO}_{2}$ emisyonuyla birlikte, $\mathrm{NOx}$ veya azot oksitler, gürültü, iklim değişikliği, ekolojik denge gibi çevresel etkilere neden olmaktadır (Oto ve Çobanoğlu, 2011).

Havalimanı yer seçiminde birçok topoğrafik şartlar, yerel hava koşulları gibi birçok kriter bulunmaktadır. Bunlardan bir tanesi düz arazi varlığıdır (Özür, 2018, s. 16). Ülkemizde özellikle Karadeniz Bölgesi'nde arazi koşulları sebebiyle yeterli alan bulunamamaktadır. Bu nedenle denizin doldurulmasıyla havalimanı inşa edilmiştir. Dolgu alanları sebebiyle olumsuz çevresel etkiler çeşitlenmekte ve su kirliliği, denizlerin korunması konuları da önlem alınması gereken konular olarak karşımıza çıkmaktadır.

\section{Materyal ve Yöntem}

Bu çalışmada büyük oranda inşaatı biten Artvin-Rize Havalimanı'nın ulaşım ve çevre yönünden olumlu ve olumsuz etkileri araştırılmaktadır. Konulara ilişkin bilgiler tez, dergi makaleleri, kurum raporları, bilimsel çalışmalar araştırılmış, bu çalışmalar yorumlanarak, grafikler, konuya ilişkin çizelgeler, bölgeye ilişkin uydu görüntüleri, harita ve şekillerle desteklenmektedir. İkinci bölümde bilimsel araştırma ve bulgularla havalimanlarının çevreye etkileri, çevresel etkileri hakkında bilgiler verilmiştir. Japonya ve Hong Kong dolgu havalimanları, dünya örnekleri olarak seçilmiştir. Havalimanlarının teknik bilgileri uydu görüntüleriyle desteklenmiştir. Üçüncü bölümde çalışma alanı Artvin ve Rize illeri hakkında kısa bilgiler, havalimanlarının yerleşimlere uzaklıkları, havalimanı projesinin olumlu ve olumsuz yönleri, Artvin-Rize Havalimanı hakkında teknik bilgiler verilmiştir. Artvin-Rize Havalimanı'nın olası çevresel etkileri detaylandırılmıştır. Elde edilen bulgular neticesinde sonuçta havalimanı yer seçimi ve çevre ilişkisinin önemi vurgulanarak, iyileştirme önerileri sunulmuştur.

\subsection{Havalimanları ve Çevreye Etkileri}

Havayolu ulaşımı giderek artan bir hızla büyümektedir. Sunduğu hizmetler, ulaşımdaki rahatlık, hız ve konfor ile kullanıcı sayısını da artırmaktadır. Havalimanları uçak pisti, uçak bakım-ikmal hizmetleri, pist alanları, kendi sit alanı içindeki yolları ile geniş alanlar kaplayan tesislerdir (Özür, 2018, s. 18). Bu durum çevresel etkileri de beraberinde getirmektedir. Havalimanları faaliyetleri sonucu ortaya çıkan çevresel etkilere yönelik çalışmalar ve yasal düzenlemeler üzerine çalışan uluslararası birçok kurum/kuruluş ve organizasyon bulunmaktadır (Durmaz, Küçükönal, Özen ve Banar, 2007). Bunlar arasında ICAO (Uluslararası Sivil Havacılık Teşkilatı), IATA (Uluslararası Hava Taşımacılığı Birliği), ACl (Uluslararası Havalimanları Konseyi), EUROCONTROL (Avrupa Hava Seyrüsefer Emniyeti Teşkilatı), ACRP (Havaalanı Araştırma İşbirliği Programı) gibi kuruluşlar örnek verilebilir (Oto ve Çobanoğlu, 2011). Bu durumun bir dezavantajı ise farkıı kuruluşlara üye ülkeler arasında yasal düzenlemelerin uygulanmasında yaşanan 
sıkıntılardır. Çevresel etkilere yönelik çalışma ve yasal düzenlemelerin uygulanması, denetlenmesi ve etkinliğinin artırılması için uluslararası düzeyde tek bir organizasyonun varlığı önem kazanmaktadır. Bunun için de hükümetler bazında temsil edilen ve havaalanı faaliyetleri çevresel etkileri konusundaki çalışmalarının yeterli olduğu ICAO, tek yetkili organizasyondur (Durmaz ve diğerleri, 2007).

Ülkemizdeki havalimanlarında Sivil Havacılık Genel Müdürlüğü’nün geliştirdiği "Yeşil Havalimanı Projesi" ve "Engelsiz Havalimanı Projesi" ile sürdürülebilirlik amaçlı çalışmalar yapılmaktadır. Öte yandan TS EN 9001 Kalite Yönetim sistemi, TS EN 14001 Çevre Yönetim Sistemi, TS 19001 iş̧ Sağlığı ve Güvenliği Standardı, TS Müşteri Memnuniyeti Standartları yer almaktadır (Oto ve Çobanoğlu, 2011).

Havalimanları giderek gelişen teknoloji ile daha verimli, daha zararsız hale getirilmeye çalışılsa da çevrede oluşturduğu etkiler önemini korumaktadır. Hava taşıma işlemleri $60^{\prime} l ı$ yıllardan günümüze kadar geçen zaman içinde \%75 daha sessiz ve \%70 daha yakıt verimli hale gelmiştir (Havaalanları Daire Başkanlığı, 2010). Öte yandan ise dünyadaki yakıt tüketiminde sivil havacılık \%5-6'lık bir paya sahiptir (Oto ve Çobanoğlu, 2011). ABD'de Ulaştırma Araştırma Kürsüsü'ne göre (TRB) sivil havacılığın oluşturduğu çevre etkileri; küresel iklim değişikliği, hava kirliliği, salımlar, ekoloji ve doğal habitat, gürültü, arazi ve malzeme kullanımı, enerji tüketimi, su tüketimi, su kirliliği ve atıklar konusunda yoğunlaşmaktadır (Oto ve Çobanoğlu, 2011). Bu etkilere ek olarak toprak kirliliği de çevresel etkilerden birisidir (Özür, 2018, s. 19).

Küresel bazda $\mathrm{CO}_{2}$ gazı emisyonunun \%2'sini havacılık kaynaklı faaliyetler oluşturmaktadır. Ulaştırma içinde üretilen $\mathrm{CO}_{2}$ gazı emisyonunun \%12'si havacılık kaynaklıdır. Emisyonun \%80'lik kısmını $1500 \mathrm{~km}$ ve üzeri mesafelerde gerçekleşen uçuşlar (Erel, 2014, s. 44) oluştursa da havayolu ulaşım ağının küresel çapta geldiği noktaya bakılacak olursa oluşan emisyonun da küresel çapta olduğu görülmektedir. Her yıl 600 milyon ton $\mathrm{CO}_{2}$ gazı yayılmakta ve bu değer Afrika kıtasının yılda yaydığı $\mathrm{CO}_{2}$ gazına eşittir (Erel, 2014, s. 43). Emisyon değerleri bu şekilde devam ederse 2050 yılına gelindiğinde \%2'lik değer \%3 oranlarına ulaşabilecektir (Oto ve Çobanoğlu, 2011). Biyoyakıtlar atmosferik karbondioksitten elde edildiklerinden kullanımları sonucu atmosferdeki net karbondioksit miktarını artırmazlar. Dolayısıyla $\mathrm{CO}_{2}$ gazı emisyonu açısından bu olumlu bir sonuçtur. Bu nedenle alternatif yakıt çalışmaları ciddi bir öneme sahiptir (Erel, 2014, s.44) $\mathrm{CO}_{2}$ gazı emisyonunun yanında NOx veya azot oksitleri de sera gazları olarak neden oldukları iklimsel etkiler ve asit yağmurları yanında insan sağlığı üzerinde de ciddi sorunlar oluşturabilmektedir. Koku algılamada sıkıntı, solunum direnci, akciğer difüzyon kapasitesi azalması, akciğer fonksiyonlarında değişime sebep olabilmektedirler (Erel, 2014, s. 44).

Havayolu ulaşımında çevresel etkilerin yanında gürültü de ciddi bir problem olarak karşımıza çıkmaktadır. Hava araçlarının neden olduğu doğrudan veya dolaylı gürültü, insanlar ve hayvanlar üzerinde olumsuz etkilere sahiptir. İnsanlarda işitme kayıpları, yüksek tansiyon, bağışıklık sisteminde aksaklıklar, astım gibi hastalıklar örnek verilebilmektedir. Gürültünün etkileri kaynağı olan havacılık faaliyetlerine olan yakınlıkla artış gösterebilmektedir (Erel, 2014, s. 45).

Öte yandan toprak kirliliği de gözden kaçırılmaması gereken bir diğer çevresel etkidir. Havacılık tesislerinden çıkan atıklar, kullanılan kimyasal maddeler doğru bertaraf edilmedikleri takdirde toprağa karışıp, kirliliğe sebep olmaktadır. Bu nedenle havalimanının konumlandırıması da önem kazanmaktadır. Ülkemizde 50 ilde 55 adet havalimanı bulunaktadır. Havalimanları konumlarına göre sınıflandırılarak incelendiğinde \%60'ı yani 32 tanesinin verimli tarım arazilerinde yer aldığı sonucu çıkmaktadır (Özür, 2018, s. 17). Şehir yerleşiminden uzakta olan havalimanlarına erişim amacıyla yapılan yollarla birlikte zamanla işyeri ve konutların gelmesiyle havalimanı yerleşimle bütünleşik hale gelmektedir. Bu durumda tarım arazileri bölünmekte ve tarımsal faaliyetler aksamaktadır.

\subsection{Dünya Örnekleri: Japonya Kansai Havalimanı ve Hong Kong Havalimanı}

Japonya'nın Osaka kentinde suni bir adanın üzerine inşa edilmiştir (Şekil 1). 1994 yılında hizmete açılan havalimanının çarpıcı özelliklerinden biri mimari yapısıdır. $1.7 \mathrm{~km}$ terminal binası uzunluğu ile dünyanın en uzun havalimanı terminal binası unvanı taşımaktadır. 42 adet biniş kapısı bulunmakta olup günlük yaklaşık 80.000 yolcuya hizmet vermektedir (Nergiz, 2019). 


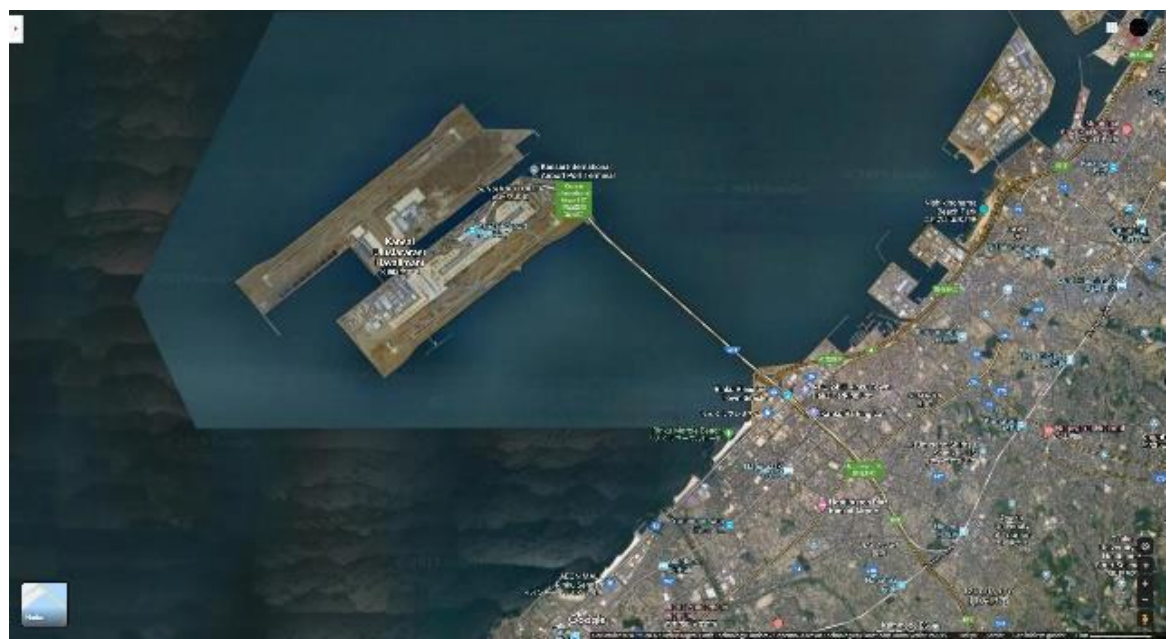

Şekil 1. Japonya Kansai havalimanı (Google Earth Uydu Görüntüsü, 2020)

Hong Kong Chek Lap Kok Havalimanı, 6 Temmuz 1998 yılında Chek Lap Kok ( $3 \mathrm{~km}^{2}$ ) ve Lam Chau $(0.1$ $\mathrm{km}^{2}$ ) adalarının düzleştirilerek ve $9.4 \mathrm{~km}^{2 \prime}$ lik deniz dolgusu ile yapılımıştır (Şekil 2). Yolcu kapasitesi 2017 yılında 72,9 milyona ulaşmıştır (Tulan ve Ercoşkun, 2019).

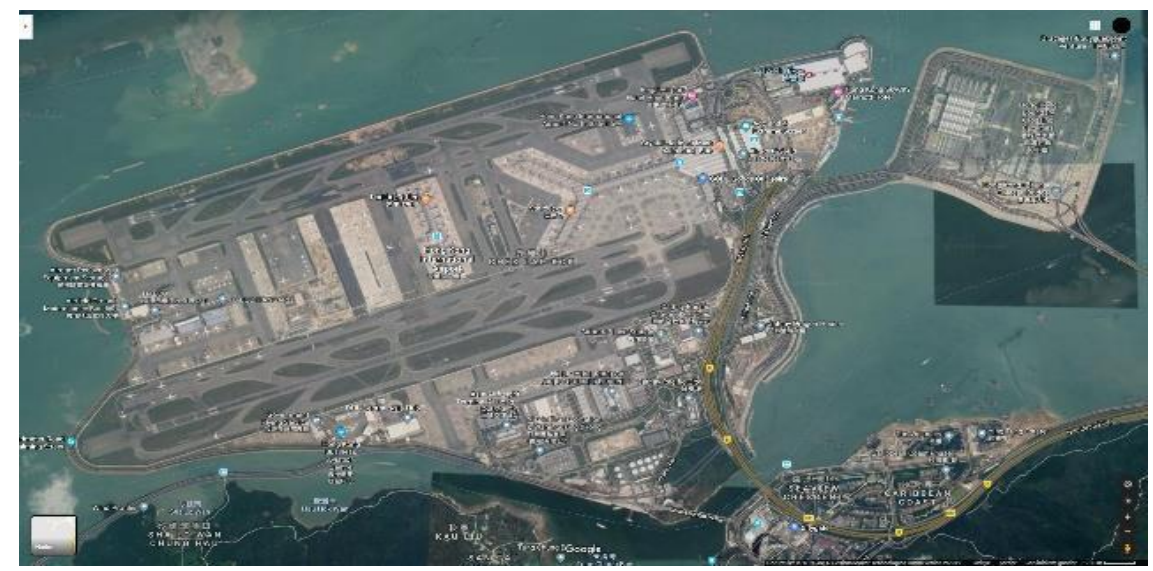

Şekil 2. Hong Kong Chek Lap Kok havalimanı (Google Earth Uydu Görüntüsü, 2020)

Proje, kent merkezini havalimanına bağlamak amacıyla uzun bir otoyol, köprü ve tünel inşasını da kapsamaktadır. Havalimanın terminal binası Dubai Havalimanı Terminal Binası (1.7 milyon $\mathrm{m}^{2}$ ), Pekin Havalimanı Terminal Binası'ndan $\left(986.000 \mathrm{~m}^{2}\right)$ sonra $570.000 \mathrm{~m}^{2}$ lik terminal binasıyla dünyanın üçüncü büyük terminal binasına sahiptir. Günümüzde talebi karşılamada yetersiz kaldığından genişletme çalışmaları yapılmaktadır (Nergiz, 2018).

Ülkemizde Karadeniz Bölgesi'nde yer alan Trabzon Havalimanı, Doğu Karadeniz'in yolcu yükünü taşımaktadır. Yolcu sayısının yüksek olması, havalimanın çevre illere olan mesafesi gibi nedenler yeni bir havalimanı intiyacı doğurmuştur. Bölgeye yapılması planlanan ve 2017 yılında inşaatına başlanan Artvin-Rize Havalimanı dünyada Japonya ve Hong Kong Havalimanlarından sonra dördüncü; Türkiye'deki dolgu alanına yapılacak Ordu-Giresun Havalimanı'ndan sonraki ikinci havalimanı olma özelliğini taşımaktadır.

\section{Bulgular ve Tartışma}

Bu bölümde, Artvin ve Rize illerinin coğrafik özellikleri, havalimanının yatırım yönüyle bölgeye olumlu etkileri, Artvin-Rize Havalimanı'na ait teknik bilgiler, olumsuz çevresel etkileri başlıklar halinde yer almaktadır.

\section{1. Çalışma Alanı: Artvin-Rize Havalimanı}

Karadeniz Bölgesi'nin doğusunda yer alan ve Karadeniz'e kıyısı olan Rize'nin toplam yüzölçümü 3.920 $\mathrm{km}^{2}$ büyüklüktedir. İklim olarak bol yağış alan ve dengeli sıcaklık rejimi turizm açısından avantajlı bir durumdur. Rize sınırları içerisinde 5 km'den uzun 23 adet akarsu bulunmakta olup bunlardan 16 tanesi Karadeniz'e ulaşmaktadır. Turistik yerlerden biri olan Fırtına deresi 68 km uzunluğa sahiptir. Hatta 
kolları Durak deresi 33 km, Hala deresi 32.5 km uzunluktadır. Bölge genel olarak dağılı ve engebelidir. Topoğrafik olarak farklıııklar göstermekte olup kıyı şeridi ve alüvyon düzlükleri, derin vadilerle yarılmış dağlık saha ve yüksek dağlık daha ve buzul topoğrafyası olmak üzere üç bölümde incelenmektedir (Rize il Tarım ve Orman Müdürlüğü, 2021).

TÜik 2019 verilerine göre Rize'nin 343.212 nüfusu bulunmaktadır (Şekil 3). Rize Merkez, Çayeli, Ardeşen, Pazar başta olmak üzere 12 ilçesi bulunmaktadır. Havalimanı şantiyesinin yakın mesafesinde bulunan Pazar, Ardeşen ve Çayeli ilçelerinin nüfusları sırasıyla 31.527, 41.084, 44.304 kişidir (Türkiye İstatistik Kurumu [TÜiK], 2019).

Artvin'in toplam yüzölçümü 7359 km² büyüklüktedir. İklim olarak kışları lık, yazları sıcak yaşanmakta ve yüksek oranda yağış almaktadır. İl sınırları içerisinde en büyük akarsu güney-kuzeydoğu yönündeki Çoruh Nehri'dir. Barhal, Murgul ve Hatilla Dereleri önemli kollarıdır. Artvin ve çevresinde Doğu Karadeniz Dağları, Mescit Dağları ve Yalnızçam Dağları bulunmaktadır. Öte yandan biyoçeşitlilik açısından önemli alanlar Camili Yöresi, Karçhal Dağları, Hatilla Vadisi Milli Parkı ve Şavşat KaragölSahara Milli Parkı'dır (Yüksek ve Ölmez, 2002).

Doğu Karadeniz Bölümü’nde yer alan Artvin 2019 TÜiK verilerine göre 170.875 nüfusa ve 7.359 km²'lik yüzölçümüne sahiptir. ill Merkezi ile birlikte 9 ilçesi bulunmaktadır ancak nüfusun büyük bir çoğunluğu merkez ilçe ile birlikte Hopa (22.775), Borçka (22.831), Arhavi 21.003) ve Yusufeli (20.154) gibi ilçe merkezlerinde yaşamaktadır (Şekil 3) (TÜiK, 2019).

NÜFUS

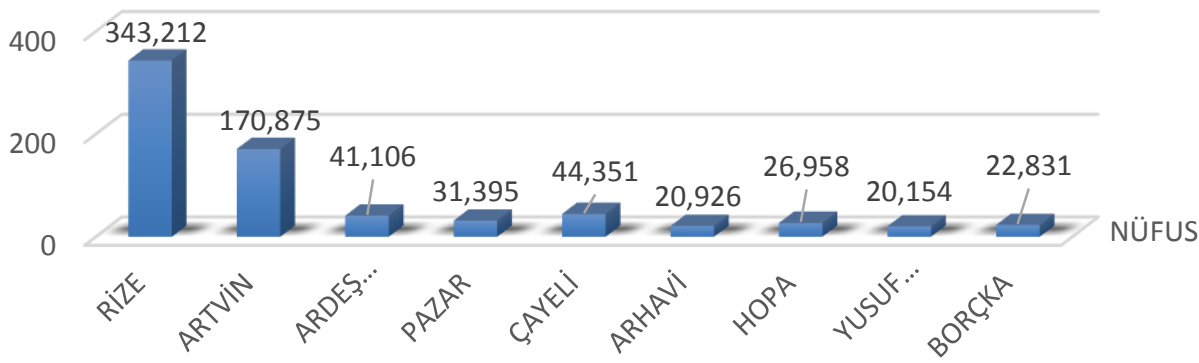

Şekil 3. il ve ilçelerin nüfus bilgileri (TÜiK, 2019)

Rize, komşusu Trabzon, Artvin, Erzurum ve Bayburt ile birlikte Karadeniz turlarının bir durağıdır. Bahar ve yaz aylarında yerli ve yabancı turist yoğunluğu yaşanmaktadır. İ Kültür ve Turizm Müdürlüğünden alınan verilere bakıldığında turist potansiyeli her geçen yıl artmaktadır (Çizelge 1).

Çizelge 1. Yıllara göre turist sayısı-Rize (Rize İ Kültür ve Turizm Müdürlüğü, 2020)

\begin{tabular}{cccc} 
YIL & YERLi & YABANCI & TOPLAM (kişi) \\
\hline 2007 & 417.338 & 57.975 & $\mathbf{4 7 5 . 3 1 3}$ \\
\hline 2008 & 433.415 & 58.415 & $\mathbf{4 9 1 . 8 3}$ \\
\hline 2009 & 437.817 & 58.729 & $\mathbf{4 9 6 . 5 4 6}$ \\
\hline 2010 & 489.731 & 69.407 & $\mathbf{5 5 9 . 1 3 8}$ \\
\hline 2011 & 509.911 & 61.217 & $\mathbf{5 7 1 . 1 2 8}$ \\
\hline 2012 & 524.021 & 61.675 & $\mathbf{5 8 5 . 6 9 6}$ \\
\hline 2013 & 581.465 & 68.417 & $\mathbf{6 4 9 . 8 8 8}$ \\
\hline 2014 & 615.053 & 71.116 & $\mathbf{6 8 6 . 1 6 9}$ \\
\hline 2015 & 616.889 & 73.459 & $\mathbf{6 9 0 . 3 4 8}$ \\
\hline 2016 & 602.814 & 76.059 & $\mathbf{6 7 8 . 0 5 9}$ \\
\hline 2017 & 761.413 & 105.404 & $\mathbf{8 6 6 . 8 1 7}$ \\
\hline 2018 & 855.323 & 121.171 & $\mathbf{9 7 6 . 4 9 4}$ \\
\hline 2019 & 889.837 & 134.173 & $\mathbf{1 . 0 2 4 . 0 1 0}$
\end{tabular}


Rize'de birçok turistik yer bulunmaktadır. Yayalar, tarihi kaleler, rafting yapılabilecek potansiyeldeki derler turistik yerlerin birkaçıdır. Çizelge 2 'de ise turistik alanların şantiye alanına uzaklıklarına yer verilmiştir. Turizm alanlarına olan yakınlık görülmektedir.

Çizelge 2. Turistik yerlerin şantiye alanına uzaklıkları

\begin{tabular}{lc}
\hline TURISTiK YERLER & HAVALIMANINA UZAKLIK (km) \\
\hline Palovit Şelalesi & 51,9 \\
\hline Anzer Yaylasi & 123 \\
\hline Zil Kalesi & 45,6 \\
\hline Kaçkar Dağlari Milli Parki & 82,8 \\
\hline Ciha Kalesi & 14 \\
\hline Polakcur Yaylasi & 58,4 \\
\hline Şenyuva Köprüsü & 39,5 \\
\hline Ovit Yaylasi & 122 \\
\hline Çağrankaya Yaylasi & 68,6 \\
\hline Rize Kalesi & 36 \\
\hline Elevit Yaylasi & 67,1 \\
\hline Amlakit Yaylasi & 83,8 \\
\hline Avusor Yaylasi & 61,5 \\
\hline Firtına Deresi & 43,8 \\
\hline Gito Yaylasi & 32,3 \\
\hline Samistal Yaylasi & 65,4 \\
\hline Çinçiva Köyü & 40 \\
\hline Gelintülü Şelalesi & 51,6 \\
\hline Pokut Yaylasi & 51,9 \\
\hline
\end{tabular}

\subsection{Artvin-Rize Havalimanı İnşaatı}

Artvin Rize Havalimanı Projesi'nin inşasına, T.C. Ulaştırma, Denizcilik ve Haberleşme Bakanlı̆̆ı, Altyapı Yatırımları Genel Müdürlüğü tarafından, Rize'nin Pazar ve Yeşilköy yerleşimleri arasında 3 Nisan 2017 yııında başlanmıştır. Projenin temel amacı Rize'nin ve çevresindeki illerin hava ulaşımında güvenli, hızı ve temiz bir ulaşım yoluna kavuşmasını sağlamaktır (Ulaştırma, Denizcilik ve Haberleşme Bakanlığı, 2016).

Havalimanı konumu itibariyle Rize'ye daha yakın, Artvin'e daha uzak bir mesafededir. Artvin ile Rize birbirine komşu iki il olmasına rağmen Artvin'in yalnızca Arhavi ve Hopa ilçelerinin havalimanına ulaşılabilirliği yüksektir. Söz konusu havalimanı projesi Rize ili sınırları içerisinde kalmaktadır (Çizelge 3). Rize'ye ve Artvin'e gitmek isteyen yolcular, Trabzon Havalimanı'nı kullanmaktadır. HAVAŞ ile günde 7 sefer düzenlenmektedir. HAVAŞ yolcu alma noktaları toplamda havalimanı dâhil 11 tanedir (Otobüs servis noktaları, 2021). Çizelge 3'te Hopa, Arhavi, Ardeşen, Pazar, Çayeli ve Rize HAVAŞ noktalarının Trabzon Havalimanı ve Artvin-Rize Havalimanına olan uzaklıkları verilmiştir. Ancak Trabzon Havalimanı'ndan HAVAŞ seferleriyle ulaşım sağlansa da uzaklık ulaşımı olumsuz etkilemektedir.

Çizelge 3. İ ve ilçelerin havalimanlarına olan uzaklıklarının karşılaştırılması

\begin{tabular}{ccc}
\hline iller & Trabzon Havalimanı (km) & Rize-Artvin Havalimanı (km) \\
\hline Rize & 72 & 34 \\
\hline Artvin & 220 & 120 \\
\hline Çayeli & 92 & 15 \\
\hline Pazar & 110 & 4,7 \\
\hline Ardeşen & 120 & 14 \\
\hline Arhavi & 150 & 48 \\
\hline Hopa & 170 & 60 \\
\hline & íki Havalimanı Arasındaki Uzaklık: $\mathbf{1 6 0} \mathbf{~ k m}$ \\
\end{tabular}

\subsection{Artvin-Rize Havalimanı Teknik Bilgiler}

Koordinatları Nihai ÇED Raporu'nda yer alan Artvin Rize Havalimanı yaklaşık 766 hektar olup bu alanın yaklaşık 260 hektarlık bölümüne dolgu yapılması planlanmıştır (Ulaştırma, Denizcilik ve Haberleşme Bakanlığı, 2016) (Şekil 4). 


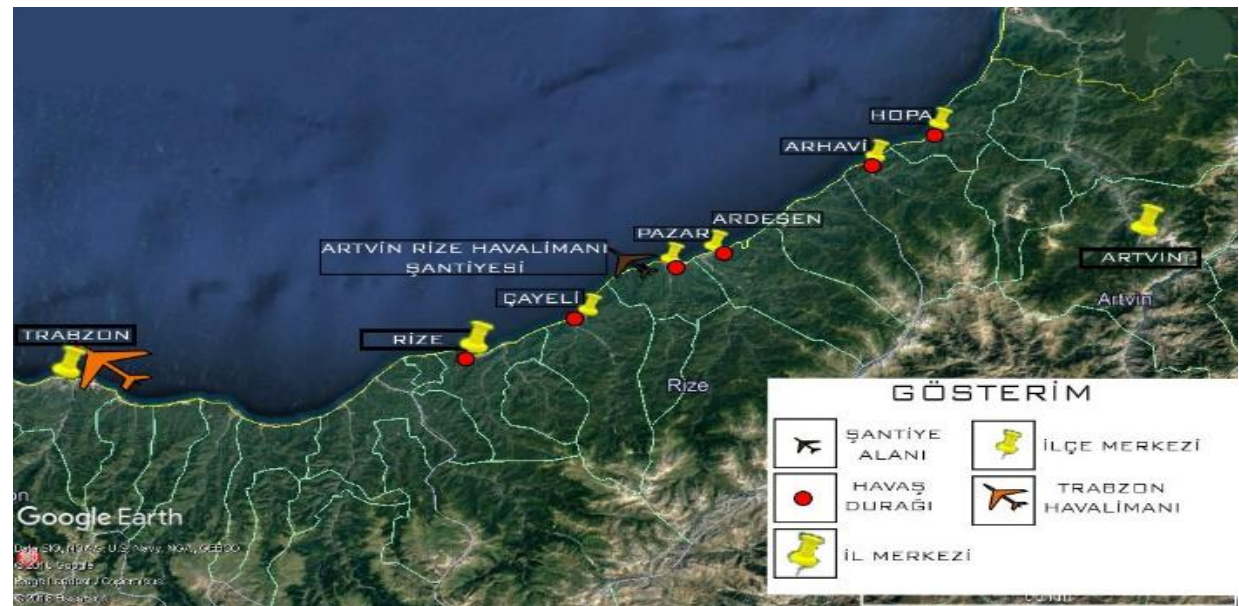

Şekil 4. Proje sahası ve mevcut havalimanının il ve ilçelere göre konumu (Google Earth Uydu Görüntüsü, 2020).

Ülkemizdeki ilk örnek olan Ordu Giresun havalimanında 20.000 .000 ton taş ve çakıl ile dolgu yapılmıştır (Tulan ve Ercoşkun, 2019). Artvin-Rize Havalimanı inşaatında ise, koruyucu mendirek sahasına 25 milyon ton, mendirek içi sahaya 60 milyon ton ve yaklaşma ışıları koridoruna ise 3.5 milyon ton olmak üzere toplamda 88,5 milyon ton dolgu yapılacaktır (Şekil 5), (Ulaştırma, Denizcilik ve Haberleşme Bakanlığı, 2016)
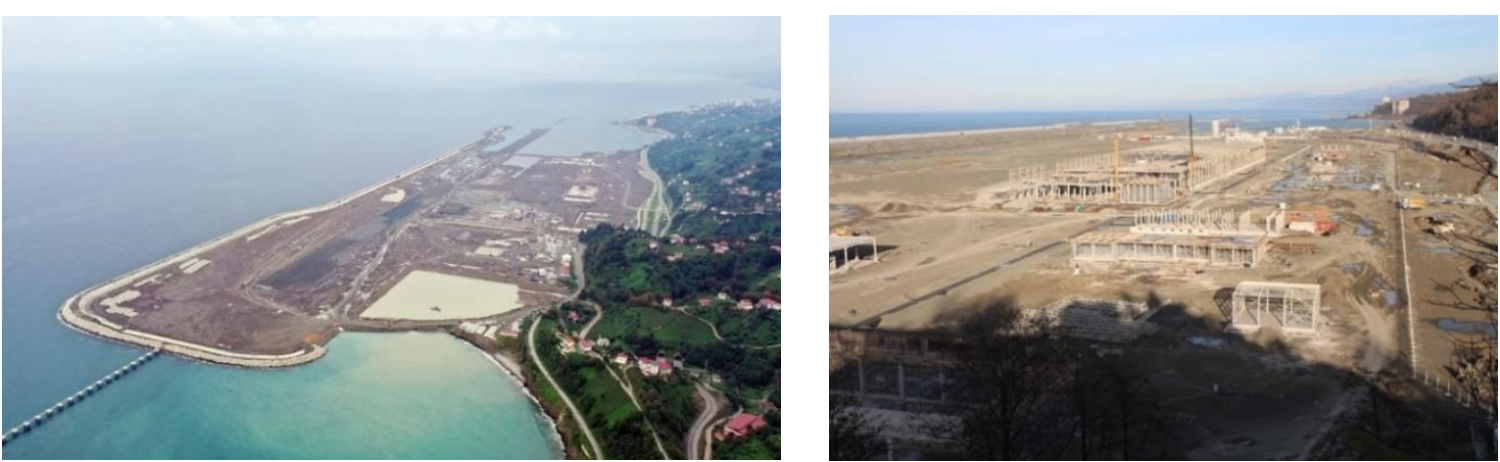

Şekil 5. İnşaat alanına ait görseller (DHA, 2021).

Inşaat aşamasında 300, işletme aşamasında ise 500 kişiye istihdam sağlayarak bölge ekonomisine katkıda bulunabileceği öngörülmektedir. Ayrıca hizmete açıldığında günlük 3000 kişiye hizmet vereceği beklenmektedir (Ulaştırma, Denizcilik ve Haberleşme Bakanlığı, 2016).

Havalimanı projesinin ekonomik ömrü 25 yıl olarak belirlenmiş, devamlılığı için gerekli bakım ve onarımın, kullanım talebi doğrultusunda yapılacağı belirtilmiştir. Öte yandan ÇED Raporu'nda 20192040 yıllarını kapsayacak şekilde yolcu tahminleri yapılmıştır. Tahminlere göre yolcu sayısı her geçen yıl artış göstermektedir (Çizelge 4) (Ulaştırma, Denizcilik ve Haberleşme Bakanlığı, 2016).

Çizelge 4. 2019-2040 yılları beklenen yolcu sayıları (Ulaştırma, Denizcilik ve Haberleşme Bakanlığı, 2016).

\begin{tabular}{cc}
\hline YILLAR & YOLCU SAYISI \\
\hline 2019 & 1.065 .000 \\
\hline 2020 & 1.074 .890 \\
\hline 2021 & 1.084 .575 \\
\hline 2022 & 1.094 .054 \\
\hline 2023 & 1.103 .313 \\
\hline 2024 & 1.112 .335 \\
\hline 2025 & 1.120 .627 \\
\hline 2026 & 1.128 .665 \\
\hline 2027 & 1.136 .439 \\
\hline 2028 & 1.143 .942 \\
\hline 2029 & 1.151 .158 \\
\hline 2030 & 1.158 .062 \\
\hline 2031 & 1.164 .637
\end{tabular}




\begin{tabular}{ll}
\hline 2032 & 1.170 .884 \\
\hline 2033 & 1.176 .788 \\
\hline 2034 & 1.182 .352 \\
\hline 2035 & 1.187 .563 \\
\hline 2036 & 1.192 .409 \\
\hline 2037 & 1.196 .892 \\
\hline 2038 & 1.201 .024 \\
\hline 2039 & 1.204 .801 \\
\hline
\end{tabular}

Rize Çevre ve Şehircilik il Müdürlüğü görüşü alınarak alternatif olarak 3 adet taş ocağı belirlenmiştir. Dolgu malzemesinin nakliyesinde kullanılan kamyonların trafiği aksatmaması için önlem alınacaktır. Seçilen taş ocaklarından malzeme temini için mevcut köy yolunun kullanılmayıp yeni bir yol güzergâhının açılması düşünülmüştür. Nakliye güzergâhının belirlenmesi için Karayolları 10. Bölge Müdürlügü’nün görüşleri alınarak hareket edileceği belirtilmiştir (Ulaştırma, Denizcilik ve Haberleşme Bakanlığı, 2016).

Deniz üzerine dolgu yapılarak inşa edilecek bir hava limanı olsa da kara havalimanları ile aynı boyut ve özelliklerde piste sahip olacaktır. Yaklaşmalarla birlikte $4.500 \mathrm{~m}^{2 \prime}$ lik alanda doğu-batı yönünde denize paralel 3.000x45 m boyutlarında bir pist ve pist bağlantı yolları yapılacaktır. İç hatlarda faaliyet göstermesi planlanan Artvin-Rize Havalimanı, tüm Türk Havayolları ve özel havayolu şirketleri filosuna hizmet verebilecek şekilde tasarlanacaktır. Bunun yanında iç hatlar terminal binaları ve gerekli tüm altyapı ve üst yapı tesisleri de yapılacaktır (Ulaştırma, Denizcilik ve Haberleşme Bakanlığı, 2016).

\subsection{Artvin-Rize Havalimanı Projesinin Çevresel Etkileri}

Projenin çevreye verdiği olumsuz etkiler çizelge $5^{\prime}$ de verilmiştir. Belirtilen başlıklardan kuş göç yolları, denizlerdeki kirlilik, deniz bitkileri ve deniz canlıları, deniz canlılarının doğal yaşam alanlarının değişmesi, balıkçılığın olumsuz etkilenmesi, hava kalitesi, kamyon trafiği ve yakıt, deniz suyu kalitesi maddeleri detaylandırımıştır. Projenin olumsuz çevresel etkileri yanında bölgeye ve bölge halkına sağlayacağı olumlu etkiler de bulunmaktadır. Çizelge 5'te olumlu ve olumsuz yönler listelenmiştir.

Çizelge 5. Artvin-Rize Havalimanı́nın olumlu ve olumsuz etkileri

\begin{tabular}{l}
\hline Olumlu Yönleri \\
\hline Turistik Alanlara Yakınlık \\
\hline Turizm Alanlarına Erişim Kolaylığı \\
\hline Ulaşım Süresinin Kısalması \\
\hline İstihdam Olanağı Sağlaması \\
\hline Olumsuz Yönleri \\
\hline Balıkçılığın Olumsuz Etkilenmesi \\
\hline Hava Kalitesinin Düşmesi \\
\hline Kuş Göç Yolları \\
\hline Deniz Canlıları Popülasyonunun Azalması \\
\hline Kıyı Ve Deniz Ekosisteminde Tahribat \\
\hline Denizlerdeki Kirlilik \\
\hline Deniz Canlılarının Doğal Yaşam Alanlarının Değişmesi \\
\hline Kamyon Trafiği Ve Karbon Ayak İzinde Artış \\
\hline Deniz Suyu Kalitesi \\
\hline Atıkların Bertaraf Edilmesi \\
\hline Topoğrafyaya Müdahale \\
\hline íklim Değişikliğini Artıcı Etkisi \\
\hline Yakıt Sarfiyatı \\
\hline Gürültü Ve Oluşturabileceği Sağlık Problemleri \\
\hline Toprak Kirliliği \\
\hline Verimli Tarım Arazilerinin Tehlike Altına Girmesi \\
\hline Hava Kirliliğinin Yol Açabileceği Sağlık Problemleri \\
\hline
\end{tabular}




\subsection{Proje Alanına Ait Ornitoloji Raporları}

Kastamonu Üniversitesi Orman Fakültesi ve Karadeniz Teknik Üniversitesi Orman Fakültesi'nden ornitoloji raporlarında yer alan bilgiye göre yapılan gözlemler sonucunda proje sahası ve civarında toplam 282 kuş türü tespit edilmiştir. Bunlardan su ve deniz kuşları, toplanma alanı olarak balıkçı limanları ve ilçelerdeki çöplük alanlarını; bazen deniz kenarı üzerindeki tahkimatları veya az da olsa bulunan kumsalı kullanmaktadırlar. Proje alanı, kuşların göç yollarıyla ilgili yapılan haritalara göre ana göç yollarından Kuzeydoğu-Güney göç yolunun toplanma hunisi içinde bulunan ikincil (tali) göç yolu üzerinde bulunmaktadır. Kuşlar normal şartlarda kara üzerinden göç etmektedir. Ancak kötü hava koşulları sebebiyle deniz üzerinden de göç yolunu takip etmektedir (Şekil 6) (Ulaştırma, Denizcilik ve Haberleşme Bakanlığı, 2016).
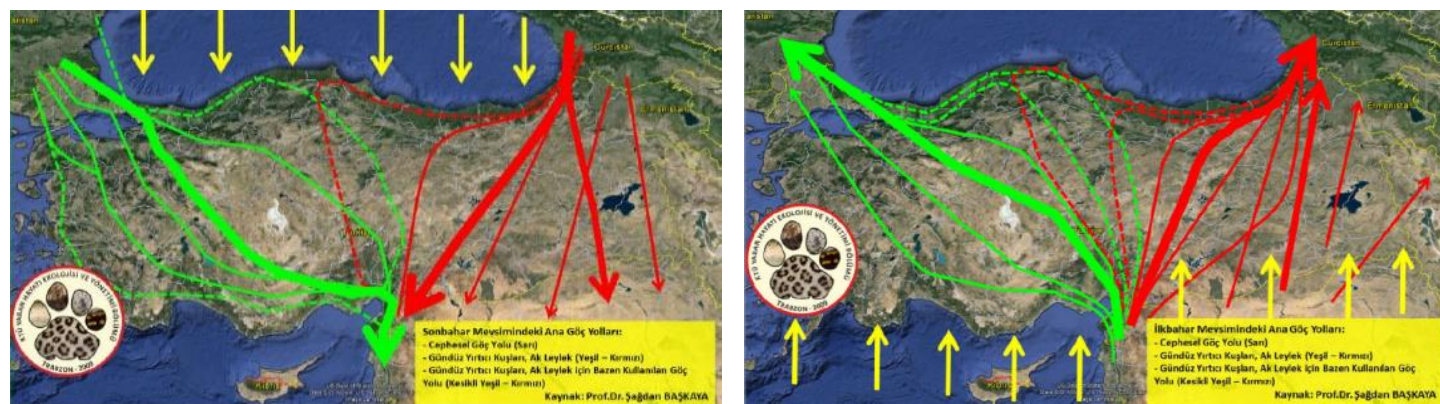

Şekil 6. İlkbahar-sonbahar kuş göç yolları (Ulaştırma, Denizcilik ve Haberleşme Bakanlığı, 2016).

ICAO (Uluslararası Havacılık Örgütü) verilerine göre kuş çarpmalarının \%90'ı iniş veya kalkış sırasında meydana gelmektedir (Ulaştırma, Denizcilik ve Haberleşme Bakanlığı, 2016). Pist dolgu alanı üzerinde inşa edilmekte olup verilen oran da göz önünde bulundurulduğunda ciddi tedbirler almak kaçınılmaz durumdadır. Tedbir anlamında havacılıkta 3.000 metrenin altındaki uçuşlarda $450 \mathrm{~km} / \mathrm{h}^{\prime}$ lik hız sınırlaması ile kuş çarpması etkisinin azaltılması planlanmaktadır (Ulaştırma, Denizcilik ve Haberleşme Bakanlığı, 2016).

Yapılan önerilerde bitki örtüsü düzenlemesi, düzenlemede kullanılabilecek bitkilerin özelliği, pistte birtakım fiziksel müdahaleler yer almaktadır. Havalimanı ve çevresinde meyve veren bitki türlerinin ekilmemesi, pist yüzeyinde suların birikmesi önlenerek solucan gibi kuşları cezbedecek koşulların önüne geçilmesi, kısa vadede korkutma, ürkütme ile kuşların alandan uzaklaştırılması, havalimanı yakınlarındaki balıkçıık yapılan limanların temiz tutulması önerilerden birkaçıdır. Ayrıca uçuşu etkileyecek kuş türleri belirlenerek arazi tespit çalışmaları yapılmalı, kalıcı müdahale yöntemleri ortaya konmalıdır (Ulaştırma, Denizcilik ve Haberleşme Bakanlığı, 2016).

\subsection{Karadeniz Florası}

Karadeniz uzun yıllar boyunca insanların geçim kaynağı, dinlence alanı ve atıkların boşaltıldığı yer olmuştur. Karadeniz, temelde kanalizasyon, petrol ve radyoaktif atıkların kirletici etkisinde kalmaktadır. Kaynakları ve sorunları kıyısı olan 6 ülkeyi, su ve havayla taşınan kirliliğin sorumluluğu Karadeniz havzasındaki 11 ülkeyi ilgilendirmektedir. Çoğu Avrupa ülkesi tehlikeli atıklarını Karadeniz'e boşaltmışlardır. Bunun yanında plansız kentleşme, arıtılmamış evsel ve endüstriyel atıklar, hızlı nüfus artışı diğer kirlilik sebepleridir. Kapalı bir deniz olması, Sakarya, Yeşilırmak, Kızılırmak gibi akarsulardan kirletici yüklerin gelmesi, Avrupa'nın kirletici yükünü taşıyan Tuna Nehri'nin sularının akması, bazı noktalarda atıkların doğrudan denize ve çevreye boşaltılması diğer kirletici nedenlerdir (Çevre Online, 2020).

Deniz kirliliği kaynaklarının oranlarına göre, deniz taşımacılığı sonucu oluşan kirlilik \%11 oranındadır. 1990 'lı yıllarda yapılan ölçüm değerlerine göre Karadeniz'e yılda 10.000 ton petrol gelmektedir. Deniz taşımacılı̆̆ı sebebiyle petrol kaynaklı kirlilik yılda 12.000 tondur. Bu da $1 \mathrm{~km}^{2}$ deniz alanında $40 \mathrm{~kg}$ petrol anlamına gelmektedir (Bulat, 2020, s. 7). Genel olarak baktığımızda Karadeniz'in kirletici unsurları şunlardır:

- Deniz taşımacılığı,

- Hava taşımacılığı, 
- Nehir yoluyla taşınan kirletici maddeler,

- Petrol ve türevi kirleticiler,

- Arıtılmamış evsel ve endüstriyel atıklar,

- Şehirler ve tarım arazilerinden taşınan kirleticiler,

- Kıyı yapılaşmaları (Gedik, 2011, s. 44).

\subsection{Deniz Bitkileri ve Canlıları}

Algler Karadeniz'de geniş yayılıma sahiptir. Ulva lactuca da Karadeniz'de bulunan alg türlerinden bir tanesidir. Denizel ekosistemin önemli bir kısmını oluşturmaktadırlar. Üretilen deniz yosunlarının $\% 50$ 'si gıda sanayinde, \%40'ı ilaç ve kozmetik sanayinde, \%10'u diğer alanlarda değerlendirilmektedir. Bu durum algler üzerinde ilgiyi artırmaktadır ve yapılan çalışmalar artmaktadır (Çebi, Soylu ve Kablan (2016).

Proje alanı ve etki alanında, Kahverengi ve Yeşil Alg popülasyonu yoğun olarak bulunmaktadır. Türler özellik olarak hızlı üreme yeteneğine sahiptir. Bu özelliklerinden dolayı geniş yayılım gösterirler ve ekolojik değişimlere çabuk uyum sağlarlar (Ulaştırma, Denizcilik ve Haberleşme Bakanlığı, 2016). Karadeniz'in oşinografik özelliklerinden düşük tuzluluk oranıyla acı su özelliği taşımaktadır. Bu durum balık türlerindeki çeşitliliğe yansımıştır. Karadeniz'de yaşayan balık türleri, soğuk sularda üremeye ve düşük tuzlulukta yaşamaya uyum sağlamıştır. Karadeniz, canlı türü açısından en fakir, tür sayısı açısından oldukça zengin bir denizimizdir (Zengin, 2019, s. 54.) (Çizelge 6).

Çizelge 6. Karadeniz'deki Türler ve Sayıları (Zengin, 2019)

\begin{tabular}{lc}
\multicolumn{1}{c}{ TÜRLER } & TÜR SAYISI \\
\hline Atlantik Akdeniz Orjinli & 109 \\
\hline Kozmopolit & 11 \\
\hline Akdeniz Endemik & 23 \\
\hline Karadeniz Yerli Tür & 34 \\
\hline Yayılımcı/Egzotik & 3 \\
\hline TOPLAM & $\mathbf{1 8 0}$ \\
\hline
\end{tabular}

Karadeniz Yerli Türleri 34 tanedir. 32 türün avcılığı yapılmakta olup, 32 tür içinde beyaz kum midyesi, deniz salyangozu ve Akdeniz midyesi gibi omurgasız türler bulunmaktadır. 32 türden 12'si ekonomik türdür ve Karadeniz'deki avın \% 98.3'ü bu 12 türden sağlanmaktadır. 12 türün içinde hamsi, istavrit, çaça ve tirsi gibi küçük pelajikler, palamut, lüfer ve kefal türleri gibi büyük pelajikler, mezgit, barbun ve kalkan gibi demersal balıklar yer almaktadır. Ayrıca Karadeniz'deki 189 balık türü 56 farklı familya ile temsil edilmektedir. Bu türler içinde vatoz, köpekbalıkları gibi 10 farklı kıkırdaklı tür, 7 adet mersin türü, 172 adet kemikli balık türü bulunmaktadır. Ekonomik olarak avcılığı yapılan türlere beyaz kum midyesi ve deniz salyangozu da yer almaktadır (Zengin, 2019, s. 54).

Karadeniz'de köpekbalı̆̆ı, denizatı, yunus ve balinalar grubundaki canlılar da bulunmaktadır. Köpekbalığı Karadeniz'deki endemik bir türdür. Omurgasız canlılar, balıklar ve büyük krustaselerle beslenirler. Endemik bir tür olan bu canlının yaşadığı derinlik ve beslendiği canlılar denize yapılan dolgudan dolayı etkilenebilmektedir (TÜDAV, 2020). Yunus ve balinalar grubundaki canlılar ise tüm denizlerimizde bulunsa da Delphinus delphis, Tursiops truncatus, Phocoena phocaena türleri Karadeniz' de bulunmaktadır (Topaloğlu, 2020).

Denizel biyo-çeşitlilik kapsamında Karadeniz'de bulunan balıklardan birkaçı, Sinarit, Lüfer, Mersin Balığı ve Kalkan'dır. Sinarit, Lüfer ekonomik değeri yüksek bir balık türüdür. Lüfer Akdeniz ve Karadeniz arasında düzenli olarak göç ettiğinden tüm denizlerimizde de görülmektedir. Mersin Balı̆̆ı hassas bir balık türüdür. Ergenlik çağına çok geç ulaşmaktadırlar. Ayrıca Mersin balıkları yüksek su kalitesine ihtiyaç duyarlar bu nedenle suyun kalitesinin düşmesi onlar için tehlikelidir. Kalkan ise 20-70 metre arasındaki derinliklerde yaşar. Diplerdeki küçük balıklar, yengeçler ve diğer küçük deniz canlılarıyla beslenmektedirler. Ülkemizde aşırı avlanma sebebiyle azalmıştır. Bunun sonucu olarak da stokları da düşmüştür (Kıraç ve Bizsel, 2014). 
Proje alanı ve etki alanının habitat özelliği açısından bulunması olası 9 balık türünden 7'si çok bol, 2'si nadir bulunmaktadır. Nadir bulunan iki türden biri bölgede gözlenmemiştir. Çok bol bulunan 7 tür genellikle 5-60 metre derinliklerde yoğun olarak bulunmaktadır (Ulaştırma, Denizcilik ve Haberleşme Bakanlığı, 2016).

Kızıldeniz ve Süveyş Kanalı yoluyla Karadeniz'in su yapısında değişimler meydana gelmeye başlamıştır. Bu olgu Karadeniz'in Akdenizleşmesi olarak tanımlanmaktadır. Karadeniz, Akdeniz suyu özelliklerini göstermeye başlamasıyla ilk defa Kızıldeniz'den gelen göçmen balığa rastlanmıştır. Bu örnek durumun ciddiyetini belirtmek adına önemlidir (Zengin, 2019, s. 54).

Türk Deniz Araştırmaları Vakfı (TÜDAV), Mısır'da 2015 yılı Ağustos ayında açılan Yeni Süveyş Kanalı Projesi'nin Akdeniz ve Karadeniz'i ekolojik olarak tehdit altında bıraktığını bildirmiştir. Projede kanalın genişletilmesi ve çift yönlü trafiğe açılmasıyla biyolojik istilaya sebep olacağını belirtmiştir. Süveyş Kanalı ile Kızıldeniz'den Akdeniz'e ve dolayısıyla Karadeniz'e ulaşabilecek zehirli deniz canlıları için önlem alınması gerektiğini vurgulamaktadır. Vakıf Başkanı'nın açıklamasına göre, yapılan bu projeyle gemi trafiğinin süresinin yarı yarıya azalması aslında ekolojik tehdidin de boyutunu göstermektedir. Önlem olarak kanaldaki doğal oluşumlu göllerin tuzluluk oranlarının artırılması biyolojik istilaya karşı bariyer görevi göreceği belirtilmiştir (TÜDAV, 2020).

\subsection{Balıkçı Barınakları ve Çekek Yerlerinin Durumu}

Proje alanının yakınlarında 4 tane barınma ve çekek yeri bulunmaktadır. Balıkçılar barınma yeri, Kirazı Balıkçı Barınağı ve Pazar Balıkçı Barınağı olmak üzere 3'ü kullanılmaktadır. Elde edilen verilere göre barınaklar tam kapasitesiyle dolmamaktadır (Şekil 7) (Ulaştırma, Denizcilik ve Haberleşme Bakanlığı, 2016).

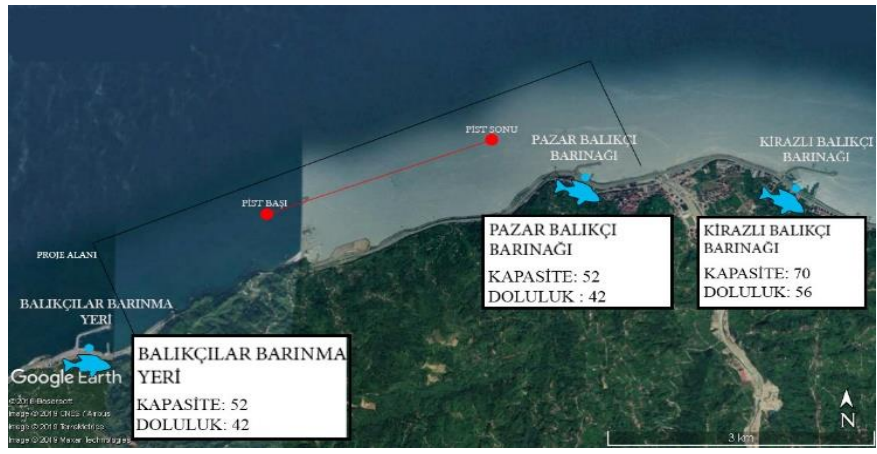

Şekil 7. Balıkçı barınaklarının konumları (Ulaştırma, Denizcilik ve Haberleşme Bakanlı̆̆ı, 2016).

TÜik 2011 yılı Su Ürünleri İstatistikleri 'ne bakıldığında, su ürünleri üretiminde artış yaşandığı görülmektedir. Genel olarak \%7,73 oranında bir artış yaşanmıştır. Su ürünleri avcılı̆̆ı \%5,93, yetiştiricilik $\% 12,95$ oranında artmıştır. Deniz ürünleri avcılığında ise genel olarak \%7,18'lik bir artış olmuştur. Hatta deniz ürünleri üretiminde \%62,43'lük bir oranla ilk sırada Doğu Karadeniz Bölgesi yer almaktadır. İkinci sırada Batı Karadeniz Bölgesi yer almıştır (TÜiK, 2011).

2019 yılı istatistiklerinde bakıldığında su ürünleri üretimi bir önceki yıla göre \%33,1 oranında artmıştır. 2011 yılına paralel şekilde yine su ürünleri avcılığı ve yetiştiricilik de artış göstermiştir; avcılık \%47,5 artışla 463.168 ton, yetiştiricilik \%18,7 artışla 373.356 ton olmuştur. Deniz ürünleri avcılığı da aynı şekilde önceki yıla göre \%52 artış göstermiştir. Hamsi balı̆̆ı 2011 yılında azalma eğiliminde olsa da 2018 yılından itibaren hızıı bir artış göstermiştir (TÜiK, 2019).

\subsection{Deniz Suyu Kalitesi}

Uçakların yıkanması, buz çözücü olarak kullanılan kimyasallar, yakıt dolum işlemlerinde oluşabilecek sızıntılar, havalimanı çevresindeki yeşil alanların ve pist etrafındaki yeşillendirme çalışmalarında kullanılan inorganik tarım ilaçları, atıkların gelişigüzel araziye bırakılması, terminal binası atık su sistemi, meydana gelebilecek uçak kazaları, havalimanı inşaatı gibi faaliyetler küresel boyutta su kirliliğine neden olmaktadır (Tulan ve Ercoşkun, 2019). 
Deniz Kalitesi Bülteni'ne göre Doğu Karadeniz kısmında özellikle havalimanının olduğu alan orta kalitededir (Şekil 8). Yapılacak olan dolgu kirliliği daha da artıracak, ilerleyen zamanda ise deniz suyuna karışacak olan ağır metaller kaliteyi düşürecektir.

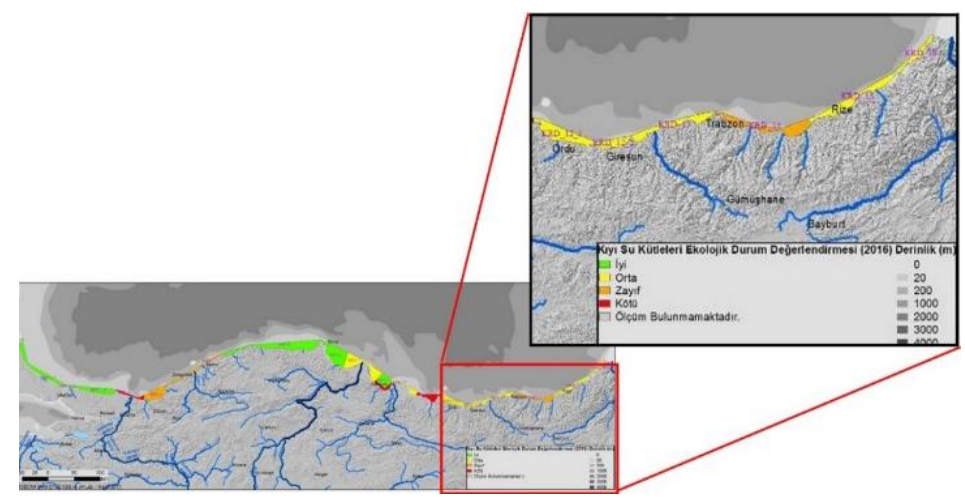

Şekil 8. Deniz kalitesi bülteni-Karadeniz Bölgesi (Çevre ve Şehircilik Bakanlığı, 2018).

\subsection{Hava kalitesi bülteni}

Çevre ve Şehircilik Bakanlığı Ulusal Hava Kalite İzleme Ağı ülke çapında 355 izleme istasyonu ile ölçümler yapmaktadır (Ulusal Hava Kalitesi İzleme Ağı, 2000). Ulusal Hava Kalitesi İndeksi, Amerika Birleşik Devletleri Çevre Koruma Ajansı (USEPA)'nın indeksini Ulusal Mevzuatımıza ve sınır değerlerimize uyarlayarak oluşturulmuştur. Partikül madde $\left(\mathrm{PM}_{10}\right)$, karbon monoksit (CO), kükürt dioksit $\left(\mathrm{SO}_{2}\right)$, azot dioksit $\left(\mathrm{NO}_{2}\right)$ ve ozon $\left(\mathrm{O}_{3}\right)$ olmak üzere 5 temel kirletici için indeks hesaplanmaktadır (Ulusal Hava Kalitesi İzleme Ağı, 2000).

Etkin ve verimli bir hava kalitesi ağı yönetimi için Türkiye genelinde İstanbul (Marmara Bölgesi), Samsun (Orta Karadeniz Bölgesi), Erzurum (Doğu Anadolu Bölgesi), İzmir (Ege Bölgesi), Adana (Akdeniz Bölgesi), Konya (Güney İç Anadolu Bölgesi), Ankara (Kuzey İç Anadolu Bölgesi), Diyarbakır (Güneydoğu Anadolu Bölgesi) merkez olmak üzere 8 bölgede Temiz Hava Merkezleri (THM) kurulmuştur. Doğu Anadolu Temiz Hava Merkezi Müdürlüğü 2016 yılında Erzurum merkezli olarak Ağrı, Ardahan, Artvin, Bayburt, Erzincan, Gümüşhane, Iğdır, Kars, Rize ve Trabzon olmak üzere 11 adet ili kapsayacak şekilde çalışmalar yapmak üzere açılmıştır (Ulusal hava izleme ağı, 2020).

Doğu Anadolu Temiz Hava Merkezi'ne bağlı illerde Kükürt dioksit ve Partikül Madde emisyonları konusunda 2019 ile 2020 yılı karşılaştırıldığında (Şekil 9);

- $\mathrm{SO}_{2}$ (Kükürt dioksit) ortalaması $5 \mu \mathrm{g} / \mathrm{m} 3$ (mikrogram/metreküp) değerinde sabit kalmıştır.

- Toz emisyonları ise çeşitli istasyonlar özelinde gerileme göstermiştir. illgili istasyonlardan proje alanına yakın istasyon olan Trabzon Akçaabat İstasyonu \%12 oranında gerilemiştir. 

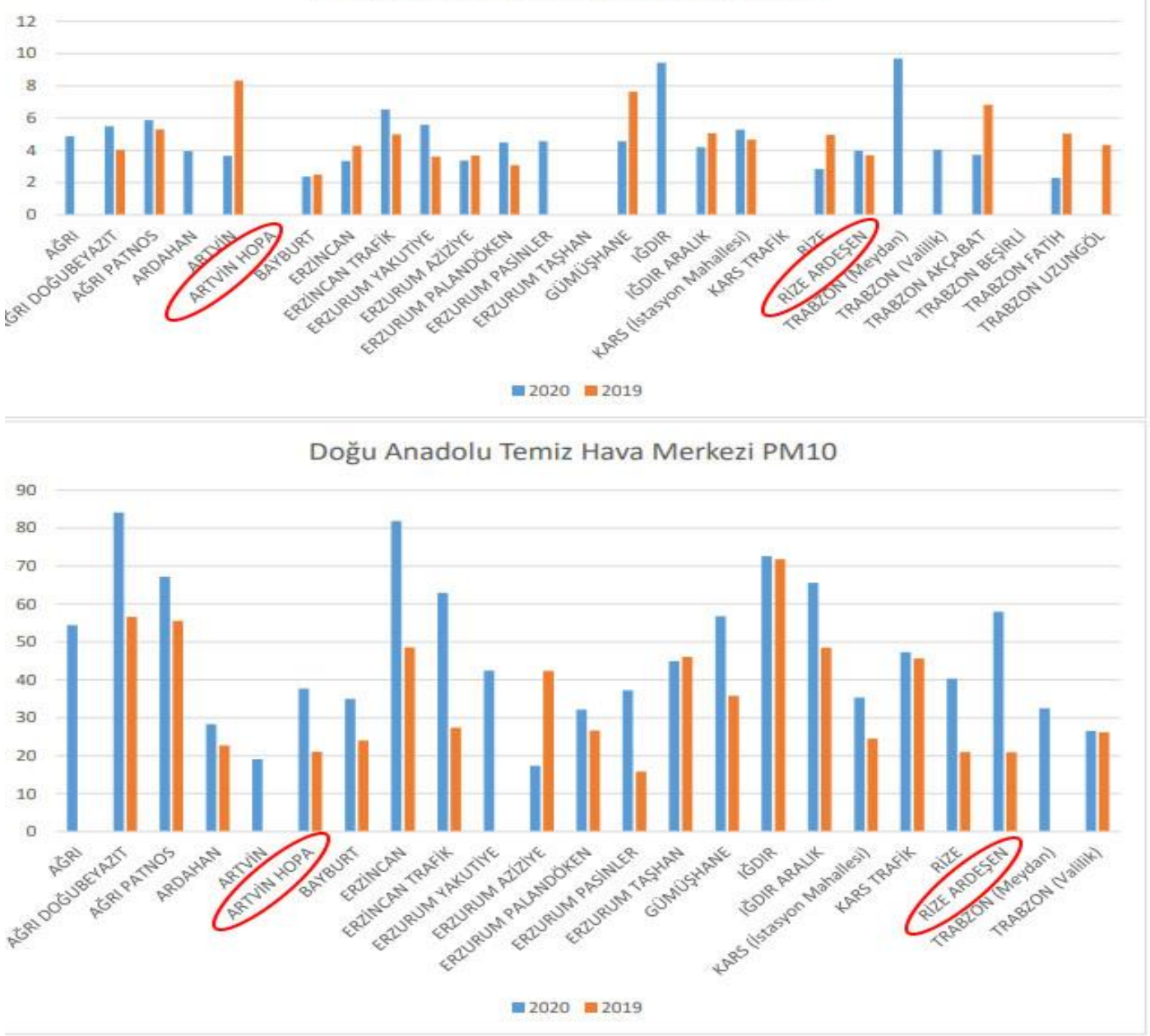

Şekil 9. Hava kalitesi bülteni (Çevre ve Şehircilik Bakanlığı, 2020).

Havalimanı inşaatının konumu itibariyle, Artvin ilinde Merkez ve Artvin-Hopa; Rize ilinde Merkez ve Rize-Ardeşen olmak üzere iki istasyon bulunmaktadır. Artvin ilinin 2018 yılı Artvin-Hopa hava izleme istasyonundan elde edilen Partikül Madde $\left(\mathrm{PM}_{10}\right)$ verileri yıllık ortalama $26 \mu \mathrm{g} / \mathrm{m} 3, \mathrm{NO}_{2}$ verileri 13 $\mu \mathrm{g} / \mathrm{m3}$, ozon verileri $56 \mu \mathrm{g} / \mathrm{m} 3$; Artvin Merkez hava izleme istasyonundan elde edilen verilere göre ise Partikül Madde $\left(\mathrm{PM}_{10}\right) 23 \mu \mathrm{g} / \mathrm{m3}$; $\mathrm{NO}_{2}$ verileri $9 \mu \mathrm{g} / \mathrm{m3}$, ozon verileri $43 \mu \mathrm{g} / \mathrm{m} 3$ şeklindedir. Partikül maddenin sınır değeri Hava Kalitesi Değerlendirme ve Yönetimi Yönetmeliği'nde saatlik $60 \mu \mathrm{g} / \mathrm{m} 3$ olarak belirlenen değeri Artvin Merkez hava kalitesi izleme istasyonunda yılda 4 gün, Artvin-Hopa hava kalitesi izleme istasyonunda ise 11 gün olduğu görülmüştür. Artvin ve Artvin-Hopa istasyonlarının her ikisinde de $\mathrm{SO}_{2}$ konsantrasyonlarının günlük $150 \mu \mathrm{g} / \mathrm{m} 3$ ve saatlik $380 \mu \mathrm{g} / \mathrm{m} 3$ düzeyinin aşılmadığı belirtilmiştir (Çevre ve Şehircilik Bakanlığı, 2019).

Çevre ve Şehircilik Bakanlığı Çevre Durum Raporu 2018 Yılı Özeti: Iller Raporu'nda Rize ilinin ve Ardeşen ilçesinin $\mathrm{SO}_{2}, \mathrm{PM}_{10}, \mathrm{NO}, \mathrm{NO}_{2}, \mathrm{NO}_{\mathrm{x}}$, Ozon parametrelerini içeren hava kalitesi ölçümleri yapılmıştır (Çizelge 7, Çizelge 8). $\mathrm{PM}_{10}$ parametresinin ölçüm değerleri 19-39 arasında değişmektedir. Partikül maddenin sınır değeri Hava Kalitesi Değerlendirme ve Yönetimi Yönetmeliği'nde saatlik $60 \mu \mathrm{g} / \mathrm{m} 3$ olarak belirlenen değeri Rize Merkez hava izleme istasyonunda yılda 13 gün, Rize-Ardeşen hava kalitesi izleme istasyonunda 9 gün olduğu belirtilmiştir. Rize ve Rize-Ardeşen istasyonlarında $\mathrm{SO}_{2}$ konsantrasyonlarının günlük $150 \mu \mathrm{g} / \mathrm{m} 3$ ve saatlik $380 \mu \mathrm{g} / \mathrm{m} 3$ sınır düzeylerinin aşılmadığı görülmektedir (Çevre ve Şehircilik Bakanlığı, 2019).

Hava Kalitesi İndeksi 'ne göre Çizelge 7 ve Çizelge 8'de görülen değerler genel anlamda hava kalitesinin iyi durumda olduğunu göstermektedir. Öte yandan Ulusal Hava İzleme Ağı'nın havalimanı inşaatının başladığı tarih olan 3 Nisan 2017 tarihli verilerine göre de bölgede hava durumu iyi kalitededir (Çevre ve Şehircilik Bakanlığı, 2019). 
Çizelge 7. Rize ili hava kalitesi ölçüm parametreleri (Çevre ve Şehircilik Bakanlığı, 2020)

\begin{tabular}{|c|c|c|c|c|c|c|c|c|c|c|c|c|c|c|}
\hline Merkez & $\mathrm{SO}_{2}$ & AGS & $\mathrm{PM}_{10}$ & AGS & CO & AGS & NO & AGS & $\mathrm{NO}_{2}$ & AGS & $\mathrm{NO}_{\mathrm{x}}$ & AGS & OZON & AGS \\
\hline Ocak & 5 & 0 & 33 & 6 & - & $\cdot$ & 8 & 0 & 12 & 0 & 20 & 0 & 35 & 0 \\
\hline Șubat & 5 & 0 & 32 & 3 & $\cdot$ & $\cdot$ & 7 & 0 & 12 & 0 & 19 & 0 & 37 & 0 \\
\hline Mart & 5 & 0 & 34 & 4 & $\cdot$ &. & 6 & 0 & 12 & 0 & 18 & 0 & 48 & 0 \\
\hline Nisan & 4 & 0 & 36 & 0 & $\cdot$ &. & 3 & 0 & 9 & 0 & 12 & 0 & 61 & 1 \\
\hline Mayis & 6 & 0 & 39 & 0 & $\cdot$ &. & 9 & 0 & 36 & 0 & 43 & 0 & 58 & 0 \\
\hline Haziran & 4 & 0 & 19 & 0 & $\cdot$ &. & 3 & 0 & 21 & 0 & 24 & 0 & 47 & 0 \\
\hline Temmuz & 4 & 0 & 20 & 0 & $\cdot$ &. & 6 & 0 & 12 & 0 & 19 & 0 & 40 & 0 \\
\hline Ağustos & 4 & 0 & 25 & 0 & $\cdot$ &. & 4 & 0 & 11 & 0 & 15 & 0 & 39 & 0 \\
\hline Eylül & 4 & 0 & 29 & 0 & $\cdot$ & $\cdot$ & 4 & 0 & 13 & 0 & 17 & 0 & 39 & 0 \\
\hline Ekim &. & 0 & $\cdot$ & $\cdot$ & $\cdot$ &. & $\cdot$ & 0 &. & 0 &. & 0 &. & 0 \\
\hline Kasim &. & 0 &. &. & $\cdot$ &. & $\cdot$ & 0 &. & 0 &. & 0 &. & 0 \\
\hline Aralik &. & 0 & . & . & $\cdot$ & . & . & 0 & . & 0 & . & 0 & . & 0 \\
\hline
\end{tabular}

Çizelge 8. Ardeşen hava kalitesi parametreleri (Çevre ve Şehircilik Bakanlığı, 2020)

\begin{tabular}{|c|c|c|c|c|c|c|c|c|c|c|c|c|c|c|}
\hline Ardeșen & $\mathrm{SO}_{2}$ & AGS & $\mathrm{PM}_{10}$ & AGS & CO & AGS & NO & AGS & $\mathrm{NO}_{2}$ & AGS & $\mathrm{NO}$ & AGS & OZON & AGS \\
\hline Ocak & 4 & 0 & 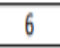 & 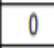 & 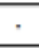 & 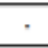 & 1 & 0 & 5 & 0 & 6 & 0 & 52 & 0 \\
\hline Șubat & 4 & 0 & 12 & 0 & . & $\cdot$ & 1 & 0 & 6 & 0 & 7 & 0 & 57 & 0 \\
\hline Mart & 4 & 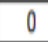 & 35 & 0 & . &. & 1 & 0 & 6 & 0 & 8 & 0 & 66 & 0 \\
\hline Nisan & 4 & 0 & 29 & 0 & . &. & 2 & 0 & 7 & 0 & 9 & 0 & 81 & 0 \\
\hline Mayis & 4 & 0 & 25 & 0 & . &. & 3 & 0 & 10 & 0 & 13 & 0 & 64 & 0 \\
\hline Haziran & 4 & 0 & 31 & 0 & . &. & 2 & 0 & 6 & 0 & 8 & 0 & 65 & 0 \\
\hline Temmur & 5 & 0 & 23 & 0 & . &. & 1 & 0 & 5 & 0 & 6 & 0 & 52 & 0 \\
\hline Ağustos & 4 & 0 & 23 & 0 & $\cdot$ &. & 1 & 0 & 4 & 0 & 6 & 0 & 48 & 0 \\
\hline Eylül & 6 & 0 & 29 & - & . & . & 2 & 0 & 3 & 0 & 6 & 0 & 53 & 0 \\
\hline Ekim & 7 & 0 & 32 & 0 &. & $\cdot$ & 2 & 0 & 3 & 0 & 5 & 0 & 46 & 0 \\
\hline Kasim & 7 & 0 & 20 & 0 &. &. & 1 & 0 & 3 & 0 & 5 & 0 & 44 & 0 \\
\hline Aralik & 3 & 0 & 7 & 0 &. &. & 2 & 0 & 4 & 0 & 6 & 0 & 47 & 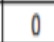 \\
\hline
\end{tabular}

Dolgu malzemesi olarak kullanılan kaya ve toprak taş ocaklarındaki kayanın patlatılıp parçalanarak elde edilmektedir. Patlatıldığı için eldesinde ve taşınmasında büyük oranlarda $\mathrm{CO}_{2}$ salınımı meydana gelmektedir. Taşınmasında kullanılan kamyonların $\mathrm{CO}_{2}$ salınımları da göz önünde bulundurulmalıdır. Binek araçlar için standartlar kat ettiği mesafeye $(\mathrm{g} / \mathrm{km})$ göre tanımlanırken, kamyonlar için motor enerji eldesiyle (g/kWh) tanımlanmıştır. Ağır Hizmet Dizel Motorları için AB Emisyon Standartları tablosunda CO, HC; NOx, PM ve Duman başlıklarında standart değerler verilmiştir. Standart değerler dikkate alınarak şantiye alanında faaliyet gösteren kamyonların salınım değerleri hesaplanmıştır (Çizelge 9) (teknikbelgeler.com, 2020).

Çizelge 9. Kamyonların emisyon değerleri

\begin{tabular}{llc}
\hline Emisyon Maddeleri & Standart Değerler (g/kWh) & $\begin{array}{c}\text { Çalışma Sonucu Ortaya Çıkan Değerler } \\
\text { (g/kWh) }\end{array}$ \\
CO & 1.5 & 4320 \\
HC & 0.46 & 1324,8 \\
PM & 0.02 & 57,6 \\
Nox & 2 & 2880 \\
Duman & 0.5 & 1440 \\
\hline
\end{tabular}

*Özgül Yakıt Tüketimi ( $\mathrm{g} / \mathrm{kWh}$ ): Motorun stabil çalışması durumunda $\mathrm{kWh}$ 'lik iş başına tüketmesi gereken yakıtın gram cinsinden değeri (Trakkulüp, 2020)

**Dolgu malzemelerini taşıyan 120 kamyon gece gündüz çalıştığından tabloda verilen standart değerler kamyonların 24 saat çalıştığı varsayılarak yapılmıştır (Manyanında, 2020).

Çizelge 9'daki değerler incelendiğinde, çalışma sonucu oluşan değerlerin standart değerlerin çok üstünde olduğu görülmektedir. İnşaat devam ettiği için yoğun bir çalışma temposu olduğundan kirlilik de artmaktadır. Çalışma dönemi bitip havalimanı hizmete açıldığında kamyonların oluşturduğu emisyonlar yerini uçak kaynaklı hava kirliliğine bırakacaktır. 


\section{Sonuç ve Öneriler}

Topoğrafik olarak havalimanı yapımı için yeterli alan bulunamaması durumunda başvurulan bir yöntem olan deniz dolgusu, birçok çevresel etki barındırmaktadır. Ordu Giresun Havalimanı'nın 2,5 katı dolgu alanı, dolgu malzemesi temini için ayrı bir yol kullanılması hem denizde hem de karada alan tüketimi oluşturmuş̧ur. Denizdeki tüketim toplamda 260 hektarlık bir alana karşılık gelmektedir. Deniz ekosistemi açısından ciddi bir kayıptan bahsetmek mümkündür. Görülebilecek etkiler hem bölgesel ve ulusal hem uluslararası olabilmektedir.

Uçakların iniş kalkışı esnasında oluşabilecek en büyük risk, kuşların pervaneye çarpmalarıdır. Bu nedenle havalimanı yapılacak bölgedeki kuş türleri, göç yolları, göç sırasındaki irtifaları, türlerin tükenme tehlikesi gibi konular üzerinde durulmalı, detaylı çalışmalar yapılmalıdır.

Dolgu malzemesinin temini için taş ocaklarından malzemeler getirilmektedir. Malzeme temini için ocakta yapılan patlatmalar, kamyonlarla taşınması sera gazı etkisi oluşturmaktadır. Artvin Rize Havalimanı'nda iki tanesi özel şirkete ait olmak üzere beş adet taş ocağından malzeme temin edilmektedir. Çok sayıda kamyonla her taş ocağından belli bir mesafe kat edilerek şantiye alanına taşınmaktadır. Bu mesafe hava kirliliğini daha geniş alana yaymaktadır. Hava kalitesi izleme istasyonlarından elde edilen bilgilere bölgenin hava kalitesi iyi durumdadır. Ancak projeyle hava kalitesinde olumsuz sonuçlar oluşabilecektir.

Su kalitesi, inşaat sırasında dolgu malzemeleriyle, yapı kullanıma açıldığında ise uçakların yakıt ikmali sırasında olabilecek sızıntılar, peyzaj düzenlemelerinde kullanılabilecek tarım ilaçları, soğuk havalarda uçağın donmasını engellemesi için kullanılan kimyasallar, zamanla dolgu malzemelerinden sızan ağır metaller nedeniyle düşmektedir.

Tür sayısı açısından zengin olan Karadeniz, balık avcılığında ulusal denizler içinde ciddi bir paya sahiptir. Karadeniz'den çıkarılan avın \%80'den fazlası Türkiye kıyılarından sağlanmaktadır. Ekonomik olarak getirisi olan, bölge halkının geçim kaynaklarından biri olan balıkçılık teşvik edilmelidir. Proje alanında 3 adet çekek yeri bulunmaktadır. Tam dolulukla çalışmamaktalar ancak doluluk oranları yaklaşık \%80 oranındadır. Türkiye İstatistik Kurumu'ndan elde edilen verilere göre 2011 ve 2019 yılı deniz ve su ürünlerindeki avcılık ve yetiştiricilik oranları artış göstermektedir. Ayrıca 2011 yılında Doğu Karadeniz artışta ilk sıraya yerleşmiş, ikinci sıra Batı Karadeniz' in olmuştur. Balıkçı barınaklarının doluluk oranları, balık çeşitliliği, ekonomik türler, oranlardaki artışlar göz önünde bulundurulduğunda Karadeniz'de balıkçılığın teşvik edilmesi daha olumlu sonuçlar doğuracaktır.

Karadeniz'deki "Akdenizleşme" Yeni Süveyş Kanalı ile daha da belirginleşmeye, denizlerimizin balık popülasyonunda değişimleri de beraberinde getirmiştir. Deniz canlılarının bu denli etkilendiği gelişmelerin olması sebebiyle daha da dikkatli davranılmalı, deniz ekosistemi ve denizel biyo-çeşitlilik korunmalıdır.

Yukarıda belirtilen etkilerden de anlaşılacağı üzere, çevresel etkiler hem uluslararası nitelikte ve uzun sürelidir. Bu nedenle önlemler almak kaçınılmazdır. Öneriler şu şekilde sıralanmaktadır:

- Proje ve alt proje için ÇED raporu hazırlanmalı,

- Dolgu için olarak seçilecek alan, canlı ekosistemi konularında detaylı incelenmeli,

- Çevre yönetim prosedürleri geliştirilmeli ve uygulanmalı,

- Projenin gerekliliği konusunda detaylı araştırmalar ve incelemeler yapılmalı,

- Uçak yakıtlarında oluşabilecek sızıntılar engellenmeli,

- Peyzaj düzenlemelerinde kimyasal tarım ilaçları kullanılmamalı,

- Buz çözücü olarak çevreci malzemeler kullanılmalı,

- Havalimanı kullanıma açıldığında oluşabilecek atıklar için atık bertaraf tesisi açılmalı,

- Kullanılan makine ve araçlara emisyon standartları uygulanmalıdır.

\section{Teşekkür ve Bilgi Notu}

Bu makale, herhangi bir tezden üretilmemiştir. Makalede ulusal ve uluslararası yayın etiğine uyulmuştur. Çalışma etik kurul izni gerektirmemektedir. 


\section{Kaynaklar}

Arabacı, G. (2010). Havaalanı yer seçiminde ve çevre düzenlemesinde vahşi yaşamın etkileri (Yüksek lisans tezi). Erişim adresi: https://tez.yok.gov.tr/UlusalTezMerkezi/tezSorguSonucYeni.jsp

Bulat, E. (2020). Türkiye'nin Karadeniz kıyısındaki deniz kirliliği ihlallerine yönelik bir çalışma (Yüksek Lisans Tezi). Erişim adresi: https://tez.yok.gov.tr/UlusalTezMerkezi/tezSorguSonucYeni.jsp

Çebi, A., Soylu, E. N. ve Kablan, S. (2016). Karadeniz'de toplanan ulva lactuca I. türünün toplam antioksidan kapasitesinin belirlenmesi. Karadeniz Fen Bilimleri Dergisi, 6(14), 22-29. Erişim adresi: https://dergipark.org.tr/tr/download/article-file/282942

Çevre ve Şehircilik Bakanlığı, Ulusal Hava Kalitesi İzleme Ağı (UHKiA). (2020). Erişim adresi: https://sim.csb.gov.tr/Intro/Uhkia

Çevre Online. (2020). Denizlerimizdeki kirlilik, Çevre Online. Erişim adresi (14.03.2020): https://cevreonline.com/denizlerimizdeki kirlilikler/

Çevre ve Şehircilik Bakanlığı, Çevresel Etki Değerlendirmesi İzin ve Denetim Genel Müdürlüğü (2018). Deniz kalitesi bülteni-Karadeniz. Erişim adresi: https://ced.csb.gov.tr/deniz-kalitesi-bulteni-i84199

Çevre ve Şehircilik Bakanlığı, Çevresel Etki Değerlendirmesi İzin ve Denetim Genel Müdürlüğü. (2020). Hava kalitesi bülteni Eylül $2020 . \quad$ Erişim adresi: https://webdosya.csb.gov.tr/db/ced/icerikler/bulten-eylul-2020-20201104102011.pdf

Çevre ve Şehircilik Bakanlığı, iller, Çevre Durum Raporları Şube Müdürlüğü Çevre Envanteri ve Bilgi Yönetimi Dairesi Başkanlığı. (2019). Çevre durum raporu- 2017 yılı özeti: iller (Yayın No. 42). Erişim adresi: https://webdosya.csb.gov.tr/db/ced/icerikler/2017_cevre_durum_raporu_ller_ozet--20190315154336.pdf

Çevre ve Şehircilik Bakanlığı, Çevresel Etki Değerlendirmesi İzin ve Denetim Genel Müdürlüğü. (2019). 2018 çevre denetimi raporu (Yayın No. 44). Erişim adresi: https://webdosya.csb.gov.tr/db/ced/icerikler/2018_cevre_denet-m_raporu20190702141555.pdf

Çevre ve Şehircilik Bakanlığı, iller, Çevre Durum Raporları Şube Müdürlüğü Çevre Envanteri ve Bilgi Yönetimi Dairesi Başkanlığı. (2020). Çevre durum raporu- 2018 yılı özeti: iller (Yayın No. 45). Erişim adresi: https://webdosya.csb.gov.tr/db/ced/icerikler/2018_cevre_durum_raporu_ller_ozet--20200318154545.pdf

DHA. (2021). Rize-Artvin Havalimanı'nda ilk uçağın iniş tarihi belli oldu, DHA. Erişim adresi (02.04.2021): https://www.ntv.com.tr

Durmaz, V., Küçükönal, H., Özen, M. ve Banar, M. (2007). Havaalanı faaliyetlerinin çevresel etkilerini azaltmaya yönelik mevzuat. Sosyal Bilimler, 5(1), 66-87. Erişim adresi: https://arastirmax.com/en/system/files/dergiler/123831/makaleler/5/1/arastirmax-havaalanifaaliyetlerinin-cevresel-etkilerini-azaltmaya-yonelik-mevzuat.pdf

Erel, C. (2014). Kyoto protokolü ışığında havacılık çevre etkileri ve önlemler. İstanbul Teknik Üniversitesi Vakfı Yayını, 65, 42-45. Erişim adresi: https://www.canerel.com.tr/images/publication/20140831ITUvd65Dergi.pdf

Gedik, K. (2011). Rize sahilinde bazı kirleticilerin mevsimsel ve hacimsel dağılımı (Yüksek Lisans Tezi). Erişim adresi: https://tez.yok.gov.tr/UlusalTezMerkezi/tezSorguSonucYeni.jsp

HAVAŞ. (2021, 10 Şubat). Otobüs servis noktaları, Erişim adresi: http://www.havas.net/tr/Hizmetlerimiz/OtobusHizmetleriVeOtopark/OtobusServisNoktalari/P ages/Trabzon.aspx

Kıraç, C. O. ve Bizsel, K. C. (2014). Sorumlu balıkçılığa geçiş. Erişim adresi: https://cemkirac.files.wordpress.com/2015/06/sorumlu_balikcilik_kitap-sad-ekog-2014.pdf 
Manyanında, (2020). Çünkü çevreci, Manyanında, Ankara. Erişim adresi (02.01.2020): https://manyaninda.com/neden_man_cunku_cevreci.php

Nergiz, A. (2018). Hong Kong Havalimanı. Erişim adresi (24.06.2018): https://www.havayolu101.com/2018/06/24/hong-kong-havalimani/

Nergiz, A. (2019). Dünyanın en uzun terminal binası. Erişim adresi (15.10.2019): https://www.havayolu101.com/2019/12/15/dunyanin-en-uzun-terminal-binasi/

Oto, N. ve Çobanoğlu, N. (2011). Çevresel biyoetik açısından sürdürülebilir havaalanları. Mülkiye 2011, 35 (273), 109-141. Erişim adresi: https://dergipark.org.tr/tr/download/article-file/30

Özür, N. (2018). Türkiye'de havalimanlarının kuruluş yerlerinin sürdürülebilir arazi kullanımı bakımından değerlendirilmesi. Türk Coğrafya Dergisi, 71, 15-25.Erişim adresi: https://dergipark.org.tr/en/download/article-file/555842

Rize Il Kültür ve Turizm Müdürlüğü. (2020). Turist istatistikleri, Rize Ill Kültür Ve Turizm Müdürlüğü, Rize. Erişim adresi (02.01.2020): https://rize.ktb.gov.tr/TR-141221/turist istatistikleri.html

Rize II Tarım ve Orman Müdürlüğü. (2021). Coğrafi yapı, Rize il tarım ve orman müdürlüğüü, Rize. Erişim adresi: https://rize.tarimorman.gov.tr/Menu/12/Cografi-Yapi

T.C. Ulaştırma Bakanlığı, Sivil Havacılık Genel Müdürlüğü Havaalanları Daire Başkanlığı. (2010). Havaalanlarında çevresel etkiler (Yayın No. HAD/T-11). Erişim adresi: http://web.shgm.gov.tr/documents/sivilhavacilik/files/pdf/kurumsal/yayinlar/hadt11.pdf

Teknik Belgeler. (2020). Avrupa emisyon standartları. Erişim adresi (02.01.2020): http://www.teknikbelgeler.com/2016/makale.php?id=40

Topaloğlu, B. (2020) Türkiye deniz ve iç sularında koruma altındaki türler. Erişim adresi (27.06.2020): http://tudav.org/calismalar/balikcilik/surdurulebilir-balikcilik/turkiye-deniz-ve-icsularindakoruma-altindaki-turler/

Trakkulüp. (2020). Gerçek/özgül yakıt tüketimi nedir?. Erişim adresi (03.01.2020): https://www.trakkulup.net/threads/gercek-ozgul-yakit-tuketimi-nedir.83183/

Tulan, H. ve Ercoşkun. Ö. (2019). Dolgu havalimanlarının çevresel etkileri: Hong Kong Havalimanı ve Ordu-Giresun Havalimanı karşılaştırması, Balkan ve Yakın Doğu Sosyal Bilimler Dergisi, 5(3), 104116. Erişim adresi: http://ibaness.org/bnejss/2019_05_03/11_Tulan_and_Ercoskun.pdf

TÜDAV. (2020). Türkiye deniz ve iç sularında koruma altındaki türler, Türk Deniz Araştırmaları Vakfı, İstanbul. Erişim adresi (27.06.2020): https://tudav.org/calismalar/balikcilik/surdurulebilirbalikcilik/turkiye-deniz-ve-icsularinda-koruma-altindaki-turler/

TÜDAV. (2020). Yeni Süveyş Kanalı Projesi 2015, Türk Deniz Araştırmaları Vakfı, İstanbul. Erişim adresi (29.09.2020): http://tudav.org/calismalar/denizel-biyocesitlilik/biyolojik-yayilim/yeni-suveyskanali-projesi/

Türkiye İstatistik Kurumu. (2019). Adrese Dayalı Nüfus Kayıt Sistemi Yıllara Ve Cinsiyete Göre il/ilçce Merkezleri Ve Belde/Köy Nüfusu, Genel Nüfus Sayımları. Erişim adresi (06.11.2020): https://data.tuik.gov.tr/

Türkiye İstatistik Kurumu. (2011). Veritabanı, Su Ürünleri İstatistikleri Haber Bülteni, Su Ürünleri İstatistikleri - Dönemi: 2011. Erişim adresi (27.06.2020): https://tuikweb.tuik.gov.tr/

Türkiye İstatistik Kurumu. (2019). Veritabanı, Su Ürünleri İstatistikleri, Haber Bülteni, Su Ürünleri Dönemi: 2019. Erişim adresi (27.06.2020): https://tuikweb.tuik.gov.tr/

Ulaştırma, Denizcilik ve Haberleşme Bakanlığı, Altyapı Yatırımları Genel Müdürlüğü, (2016). Nihai ÇED raporu- Rize havalimanı projesi ornitoloji raporu. Erişim adresi: http://eced.csb.gov.tr/ced/jsp/ek1/5647\# 
Ulaştırma, Denizcilik ve Haberleşme Bakanlığı, Altyapı Yatırımları Genel Müdürlüğü. (2016). Nihai ÇED Raporu. Erişim adresi: http://eced.csb.gov.tr/ced/jsp/ek1/5647\#

Ulaştırma, Denizcilik ve Haberleşme Bakanlığı, Altyapı Yatırımları Genel Müdürlüğü. (2016). Nihai ÇED raporu su ürünleri koop. merkez birliği verileri. Erişim adresi: http://eced.csb.gov.tr/ced/jsp/ek1/5647\#

Ulaştırma ve Altyapı Bakanlığı, Sivil Havacılık Genel Müdürlüğü. (2019). Faaliyet raporu 2019. Erişim adresi: http://web.shgm.gov.tr/documents/sivilhavacilik/files/pdf/kurumsal/faaliyet/2019.pdf

Yüksek, T. ve Ölmez, Z. (2002). Artvin yöresinin iklim, toprak yapısı, orman alanları, ağaç serveti ve ormancılık çalışmalarıyla ilgili genel bir değerlendirme. Artvin Orman Fakültesi Dergisi, 1, 50-62. Erişim adresi: http://ofd.artvin.edu.tr/tr/download/article-file/25595

Zengin, M. (2019). Karadeniz Türk balıkçılığının yüz yıllık tarihine genel bir bakış. Karadeniz Araştırmaları Enstitüsü Dergisi, 5(7), 31-67. Erişim adresi: https://dergipark.org.tr/en/pub/karen/issue/45392/584037 